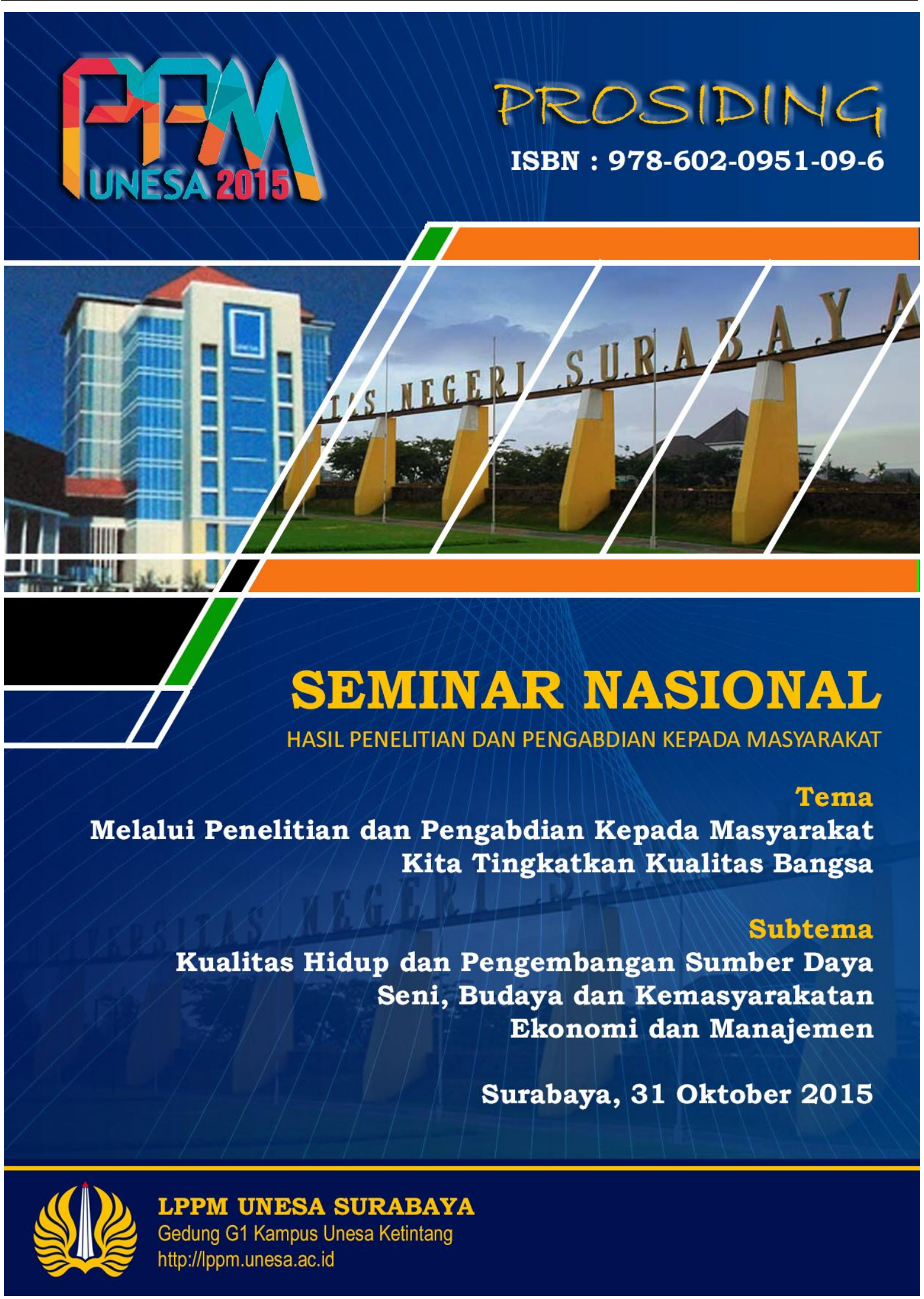




\section{KATA PENGANTAR}

Puji Syukur kehadirat Tuhan Yang Maha Esa yang telah melimpahkan Rahmat-Nya sehingga Seminar Nasional Hasil Penelitian dan Pengabdian kepada Masyarakat dengan tema "Melalui Penelitian dan Pengabdian kepada Masyarakat, Kita Tingkatkan Kualitas Bangsa"dapat terlaksana. Kegiatan seminar ini diharapkan dapat meningkatkan kuantitas dan kualitas penelitian dan pengabdian kepada masyarakat di berbagai bidang. Selain itu dapat digunakan sebagai sarana untuk saling tukar informasi hasil penelitian dan pengabdian kepada masyarakat pada berbagai bidang ilmu.

Selama ini banyak hasil penelitian yang dilakukan perguruan tinggi belum disebarluaskan atau didesiminasikan kepada pihak-pihak yang memerlukan. Untuk itu dengan penerbitan Buku Prosiding ini dapat menyebarluaskan hasilhasil penelitian dan pengabdian kepada masyarakat yang dilakukan oleh perguruan tinggi. Dengan adanya desiminasi diharapkan tidak hanya sebagai sarana untuk saling tukar informasi hasil penelitian dan pengabdian kepada masyarakat dalam bidang ilmu atau bidang kajian tertentu. Desiminasi ini akan dapat dimanfaatkan bagi masyarakat luas yang membutuhkan atau yang menaruh perhatian pada bidang-bidang yang ada dalam Buku Prosiding. Hal ini akan membawa implikasi pada penguatan peran perguruan tinggi dalam pengabdian kepada masyarakat.

Dengan adanya penerbitan Buku Prosiding ini diharapkan dapat memberikan sekapur sirih untuk meningkatkan kualitas bangsa melalui hasilhasil penelitian dan pengabdian kepada masyarakat di berbagai bidang yang dilakukan oleh perguruan tinggi. Terima kasih.

Ketua Panitia, 


\section{DAFTAR ISI}

Kata Pengantar

Hal.

Daftar Isi

Any Sutiadiningsih, Agung Prijo Budijono, dan Mokhamad Nur

Bawono

Pembuatan Alat Pengaduk Petis Dengan Metode Au Bain Marie

Dalam Upaya Peningkatan Produktivitas Kelompok UKM Petis

Asidigisianti Surya Patria, Siti Mutmainah, dan Nova Kristiana

Kerajinan Anyam Enceng Gondok Untuk Meningkatkan Ketrampilan

Kelompok Tani Wanita Srikandi

Budi Priyo Prawoto, Rini Setianingsih, dan Novita Kartika Indah

Pemberdayaan Masyarakat (Pelatihan Pengolahan Hasil Panen Lokal

Desa Trepan Menjadi Produk Bernilai Lebih Tinggi)

Budi Purwoko

Penerapan Program Mediasi Sebaya Untuk Membantu Mengatasi

Konflik Pada Siswa SMA

Choirul Anna Nur Afifah dan Veni Indrawati

Peningkatan Kemampuan Kognitif Remaja Melalui Media

Pendidikan Gizi Dan Reproduksi Online Di SMKN 6 Surabaya

Dadang Supriyatno, dan Ari Widayanti

Evaluasi Kinerja Terminal Angkutan Umum di Kabupaten Sidoarjo dalamMendukung Peningkatan Pelayanan bagi Pengguna

Evie Ratnasari

Pemanfaatan Nira Untuk Pembuatan Nata De Siwalan Bagi

Kelompok Usaha Nira/Legen Paciran Lamongan

Fransisca Januarumi Marhaendra Wijaya

Rangkaian Gerak Senam Artistik Putri Tingkat Pemula

Ginanjar Nugraheningsih

Inovasi Metode Latihan Terhadap Prestasi Olahraga

Haris Supratno

Pendidikan Lingkungan Kesehatan Berbasis Karakter ( Studi Kasus

Pondok Pesantren di Kbupaten Jombang)

Kirwani, Durinda Puspasari, dan Durinta Puspasari 
Perkembangan Industri Mebel Di Jawa Timur Dalam Era

Perdagangan Bebas Asean China

Kunjung Ashadi

IbM Korban Erupsi Gunung Kelud di Desa Pandansari Kecamatan

Ngantang

M.V. Roesminingsih, Ismono, dan I Ketut Atmaja JA

Implementasi Modul Pendidikan Lingkungan Hidup Green

Orientation Dalam Menumbuhkan Kepedulian Mahasiswa

Pendidikan Sains FMIPA Dan Siswa SMP Lab Unesa Terhadap

Lingkungan

Murtadlo

Pengembangan Pendidikan Ramah Lingkungan Bagi Anak

Berkebutuhan Khusus (ABK)

Ninik Wahju Hidajati dan Anita Susanti

IbM UKM Kripik Untuk Meningkatkan Pendapatan Melalui

Diversifikasi Produk Berbasis Limbah Umbi

Nisa Rahmaniyah Utami

Petite Fours Variasi Filling Dan Topping Buah-Buahan Tropis

Sebagai Hidangan Stand Pesta

Noortje Anita Kumaat

Pengaruh Latihan Senam Aerobic Low Impact dan Senam Yoga

Terhadap Physiological Fitness dan Psychological Fitness Wanita

Usia 30-40 tahun

Nurmi Frida Dorintan B.P.

Pemberdayaan KWT Tambak dalam Pelestarian Mangrove melalui

Tambak Ramah Lingkungan (Silvofishery) di Pasuruan Jawa Timur

Priyo Heru Adiwibowo dan Umar Wiwi

IBM Kelompok Usaha Bakso Di Karangpilang Surabaya

Rita Ismawati

Catering Diet Sebuah Inovasi Dan Kreatifitas Usaha Boga

Roy Januardi Irawan

Efektifitas Konsumsi Jus Markisa Sebagai Bahan Pengurang Rasa

Nyeri Memar Trauma Pada Atlet Pencak Silat PSHT Magetan 
Konstruksi Nilai Integritas Dalam Membangun Growing With

Character Di Unesa

Soeparno,Nur Andajani, dan Listyaningsih

Model Pengembangan Fasilitas Pejalan Kaki Dalam Mendukung

Pengoperasian Mass Rapid Transit (Monorail, Trem dan BRT) di

Wilayah Kota Surabaya

Totok Suyanto

Mengembangkan Perspektif Kewirausahaan di Perguruan Tinggi

Sebagai Upaya Meningkatkan Daya Saing PT Dalam Menghadapi

Masyarakat Ekonomi ASEAN (MEA)

Tukiran

Pendampingan Penyusunan Karya Tulis Ilmiah Bagi Guru-Guru

SMPN 1 Gresik Dan SMPN 2 Menganti

Winarsih dan Abdul Hafidz

Studi Ketersediaan Air Telaga Sebagai Sumber Air BersihDi Wilayah

Desa Glindah, Kecamatan Kedamean, Gresik

Yuliani Puji Astuti dan Dwi Nur Yunianti

Model Seleksi Beasiswa Menggunakan Fuzzy Max-Min

Yuliani dan Yuni Sri Rahayu

Pemanfaatan Mikorhiza Vesikular Arbuskular Var. Etunicatum Dan

Fasiculatum Untuk Meningkatkan Pertumbuhan Tanaman Kedelai

Pada Media Tanah Salin

\section{TEMA SENI, BUDAYA, DAN KEMASYARAKATAN}

Bambang Soeyono dan Joko Winarko

Wayang Kulit Jawa Timuran Cengkok Trowulan: Asal Usul Dan Peta

Penyebarannya

Bambang Sugito, Eko Wahyuni Rahayu, dan Warih

Handayaningrum

Eksistensi Musik U1 Daul di Madura (Tinjauan Garap Musikal dan

Persebaran Wilayah)

Eko Wahyuni Rahayu

Wayang Topeng Jati Duwur Sebagai Refleksi Nilai-Nilai Budaya

Lokal Masyarakat Jombang

Farida Hardaningrum 
Pemberdayaan Masyarakat Desa di Kabupaten Sidoarjo dalam

Mengelola Sampah Rumah Tangga

Heny Subandiyah dan Haris Supratno

Konstruksi Ajaran Islam Dalam Novel Religi Sastra Indonesia Tahun

2000-an

Mutimmatul Faidah

Tata Rias Pengantin Giri Kedaton Sebagai Khazanah Wisata Syari'ah Kabupaten Gresik

Niken Purwidiani dan Choirul Anna Nur Afifah

Pola Konsumsi Makanan Pokok Masyarakat Desa Pagendingan

Kecamatan Galis Kabupaten Pamekasan

Setyo Yanuartuti

Garap Tari Topeng Dalam Konservasi Wayang Topeng Jati Duwur Jombang

Sri Dwiyanti dan Sri Usodoningtyas

Desain Modifikasi Tata Rias Pengantin Putri Trenggalek

Sri Dwiyanti dan Nia Kusstianti

Pengembangan SDM Melalui Pelatihan Tata Rias Pengantin Bagi

Santriwati Pondok Pesantren

Sri Sulistiani

Pergeseran Makna Makanan Tradisional Jawa Timur: Berdasarkan

Pemetaan Wilayah Budaya

Warih Handayaningrum, dkk

Pengembangan Bahan Ajar Seni Budaya Tematik Berbasis

Kemipaan Di SD ( Kurikulum 2013)

\section{TEMA EKONOMI DAN MANAJEMEN}

Ari Widayanti, Dadang Supriyatno, dan Nur Andajani

IbM Pengrajin Batik Untuk Meminimalisasi Pemakaian Pewarna

Sintetis

Budihardjo Achmadi Hasyim, dan Iskandar

Meningkatkan Kualitas Dan Kuantitas Produksi Melalui Perbaikan Teknologi Produksi Dan Penataan Manajemen Pada Industri Kecil Pengrajin Tas 
Dian Savitri, Widyastuti, dan Tatag YES

Pengelolaan Manajemen Usaha Dan Media Promosi Batik Tulis

Pasuruan

Erina Rahmadyanti, Dewie Tri Wijayanti, dan Listyaningsih

IbM Usaha Jenang Rakyat Yang Mengalami Permasalahan

Lingkungan

Hariyati

Asosiasi Implementasi SAK- ETAP Dengan Kinerja Keuangan Serta Faktor Faktor Yang Mempengaruhinya ( Studi Pada Bpr Diwilayah Gerbangkertasusila )

Jun Surjanti, Dian Anita Nuswantara, Rahayu Dewi SY Mende

Analisa Faktor Penghambat Perkembangan UMKM di Kabupaten

Lamongan dengan Analisa Konten Induktif

Moch. Khoirul Anwar

Pemberdayaan Ekonomi Masyarakat Melalui Pondok Pesantren (Studi Kasus Di Pondok Pesantren Sunan Drajat Paciran Lamongan)

Mochamad Arif Irfa'I dan Diah Wulandari

Analisis Dampak Pelatihan Desain Sandal Dan Alat Pemotong

Sandal Bagi Kelompok Usaha Sandal Di Desa Wedoro, Waru,

Sidoarjo

Ni Nyoman Alit Triani

Penerapan Model Good University Governance Dalam Mendeteksi Fraud Di Universitas Bersistem BLU (Studi Kasus Universitas

Diponegoro)

Niken Purwidiani dan Mein Kharnolis

Peningkatan Kualitas Produksi Alen-Alen Pada Paguyuban Usaha Alen-Alen Di Desa Bendorejo Kecamatan Pogalan Kabupaten Trenggalek

Nindria Untarini , Yessy Artanti, dan Leksono Lestariyadi

Pemberdayaan Kelompok Pembuat Makanan Jajanan Dan Pemilik Kantin Sekolah Di Surabaya Melalui Pelatihan Produksi Dan Manajemen Usaha Sebagai Upaya Meningkatkan Pengetahuan Dan Ketrampilan Pengelolaan Usaha Kantin Sekolah 
Pengembangan Modul Kewirausahaan Dalam Upaya Menumbuhkan Jiwa Entrepreneurship Siswa SMK Di Surabaya

Titik Taufikurohmah, dan Siti Tjahjani

Analisis Minat Konsumen Kosmetik Terhadap Berbagai Jenis Krem Nanogold Sebagai Dasar Rencana Produksi Dan Rasio Penyediaan

Stok Produk 


\title{
KERAJINAN ANYAM ENCENG GONDOK UNTUK MENINGKATKAN KETRAMPILAN KELOMPOK TANI WANITA SRIKANDI
}

\author{
Asidigisianti Surya Patria ${ }^{1}$, Siti Mutmainah ${ }^{1}$, danNova Kristiana ${ }^{2}$ \\ ${ }^{1}$ Dosen Jurusan Pendidikan Seni Rupa Fakultas Bahasa dan SeniUniveristas Negeri Surabaya
}

\begin{abstract}
Abstrak: Kelompok Tani Srikandi Kelurahan Balasklumprik Kecamatan Wiyung, Surabaya merupakan sekelompok masyarakat yang kurang produktif. Tanaman liar nceng gondok yang banyak terdapat di wilayah kelurahan Balasklumprik sehingga untuk meningkatkan ketrampilan kerajinan dengan teknik anyam menggunakan bahan enceng gondok. Luaran yangdihasilkan adalah produk kerajinan berbahan enceng gondok dengan teknik anyam dan tempel, yaitu: kotak tisu, piring, mangkok, dan tas.Tim juga merancang media promosi berupa $x$-banner dan brosur untuk memasarkan produk-produk kerajinan ketika mengikuti pameran produk unggulan daerah.
\end{abstract}

Kata Kunci: Enceng Gondok, Kerajianan, Kelompok Tani

\section{Pendahuluan}

Kerajinan anyam merupakan salah satu dari kebudayaan yang dimiliki manusia sejak jaman pra sejarah dalam rangka memenuhi kebutuhan akan sandang dan perlengkapan pendukung sehari-hari. Sampai saat ini, kerajinan anyam merupakan salah satu bentuk kerajinan yang terus dihasilkan oleh sebagian masyarakat Indonesia dengan ciri khas bentuk dan ornamen yang beragam dengan menggunakan bahan yang tersedia di alam, baik bambu, pandan, rotan dan mendong. Produk kerajinan anyam dalam kehidupan manusia, selain sebagai pemenuhan kebutuhan fungsional dalam arti fisik, tetapi kehadirannya juga dalam memenuhi kebutuhan estetik. Oleh karenanya jenis barang yang diproduksi menjadi sangat bervariasi, mulai dari perlengkapan kebutuhan rumah tangga yang bersifat tradisional sampai produk-produk aksesoris interior, maupun cendera mata (Syamsudin, n.d).

Seiring dengan perkembangan zaman saat ini produk kerajinan anyam sudah merambah ke berbagai jenis keperluan seperti: cinderamata, fashion, tas, alas kaki dan lain sebagainya. Bahan yang digunakanpun mulai beragam baik dari bahan alami seperti: enceng gondok, pelepah pisang, pandan, rotan, ataupun bahan sintetis seperti: pita dan plastik. Perkembangan desainnya juga maju pesat yang disesuaikan dengan permintaan konsumen sehingga bentuk, motif dan fungsinya sudah mulai bergeser. Keanekaragaman bentuk, fungsi dan motif anyaman ini menjadikan produk anyaman mempunyai daya tarik dan ciri khas tersendiri.

Kerajinan anyam ada dan berkembang sejak jaman dahulu dan bertahan sampai hari ini. Hasil karya kerajinan anyam masih dapat ditemukan sebagai pelengkap kebutuhan yang tidak dapat dipisahkan dari kehidupan manusia. Manusia dalam kehidupannya tidak lepas dari berbagai kebutuhan. Kebutuhan yang bersifat fisik (kebendaan) dan kebutuhan rochaniah (kepuasan batin). Karya kriya anyam sebagai sebagian kecil kebutuhan fisik dari manusia. Anyam dapat ditemukan dalam pelengkapan kebutuhan sebagai alat rumah tangga. Di dapur kita dapat temukan berbagai kriya anyam antara lain: aseupan (kukusan), niru (nyiru), ayakan tetapi, mungkin sekarang sudah tidak ada (Torachman, 2009).

Anyaman adalah teknik membuat karya seni rupa yang dilakukan dengan cara menumpang tindihkan (menyilangkan) bahan anyam yang berupa lungsi dan pakan. Lungsi merupakan bahan anyaman yang menjadi dasar dari media anyam, sedangkan pakan yaitu bahan anyaman yang digunakan sebagai media anyaman dengan cara memasukkannya ke dalam bagian lungsi yang sudah siap untuk dianyam. Bahan-bahan 
anyaman dapat dibuat dari tumbuh-tumbuhan yang sudah dikeringkan, seperti lidi, rotan, akar, dan dedaunan untuk dijadikan suatu rumpun yang kuat (tampar). Sedangkan alat yang digunakan untuk mengayam masih sangat sederhana seperti pisau pemotong, pisau penipis, dan catut bersungut bundar.

Salah satu kampung di Surabaya di daerah Kebraon, Kelurahan Klego, Pekalongan, Jawa Tengah, dan pengerajin enceng gondok di dusun Jambu, Bantul yogyakarta sudah melakukan ubah manfaat enceng gondok sebagai komoditas kerajinan. Dengan kreatifitasnya para warga tersebut mampu mengubah enceng gondok menjadi barangbarang kerajinan yang mampu memberikan penghasilan dalam memenuhi kebutuhan sehari-hari. Barang kerajinan tersebut salah satunya adalah tas, korden, taplak meja, hiasan dinding, sandal, batal kursi dan dompet. dan lainnya.Bahkan mereka mampu melakukan ekspor dengan kerajinan tersebut (kompasiana.com).

Serat enceng gondok (Eichornia crassipes) memiliki tekstur yang berbeda dibanding serat dari bahan lain. Serat enceng gondok lebih kuat, tetapi tetap halus dan empuk. Hanya dengan membersihkan batang dari daunnya lalu dikeringkan dengan cara dijemur. Hasil olahan enceng gondok kemudian dianyam atau dijadikan sedemikian rupa sehingga menghasilkan produk kerajinan, seperti tas, kerajinan, dan furnitur rumah tangga. Agar kuat anyaman serat dilem dan diikat dengan benang kasur. Tampilan serat enceng gondok umumnya kusam sehingga untuk mencerahkannya digunakan cat pernis.

Sebagai salah satu industri kreatif, kriya anyam sudah mengakar dalam kehidupan masyarakat. Dalam perkembangannya sudah merambah dalam berbagai bentuk dan produk yang lebih modern jauh dari kesan tradisional seperti: alat rumah tangga dan mebel. Hal ini berarti anyaman memiliki potensi ekomomis yang luas dalam hal produk yang dihasilkan dan lagi memberikan lapangan pekerjaan.

Kelompok Tani "Srikandi" Kelurahan Balasklumprik merupakan kelompok calon pengusaha (wirausaha) yang bergerak di bidang kerajinan. Usaha kerajinan berbahan enceng gondok berpotensi dikembangkan menjadi usaha kerajinan mengingat potensi sumber daya alam berupa enceng gondok yang banyak tumbuh di wilayah Kelurahan Balasklumprik. Usaha kerajinan sendiri termasuk dalam bidang industri kreatif yang berpotensi dikembangkan dan gencar disuarakan pemerintah. Hanya saja pembinaan manajemen usaha dalam aspek manajemen produksi perlu dibina terus-menerus, terutama berkaitan dengan pengembangan desain.

\section{Metode Pelaksanaan}

Kegiatan yang dilaksanakan oleh tim pelaksana bersama mitra diuraikan dengan langkah-langkah sebagai berikut.

1. Studi Kelayakan

Berupa studi pendahuluan yang dilakukan oleh Tim Pelaksana untuk mengetahui lebih jauh mengenai kelayakan mitra mengikuti kegiatan. Tahap ini dilakukan dengan teknik wawancara dan berdiskusi dengan beberapa pengurus Kelompok Tani Srikandi Kelurahan Balasklumprik. Wawancara tersebut kemudian dilanjutkan dengan observasi langsung ke lokasi untuk mengetahui secara nyata kondisi geografis dan demografis.

Berikutnya tim pelaksana melakukan koordinasi ke dalam untuk menganalisa data yang diperoleh di lapangan untuk membuat modul dan handout yang disesuaikan dengan kondisi dan situasi kelompok Tani. Bersamaan dengan membuat modul dibuat pula prototype produk yang merupakan contoh produk yang menjadi contoh hasil akhir pada kegiatan pelatihan berlangsung. Prototype tersebut juga disesuaikan dengan kemampuan peserta, dirancang agar tidak terlalu sulit ataupun tidak terlalu mudah.

\section{Pelaksanaan Kegiatan}


Setelah waktu ditentukan dengan pasti dan ijin dari pihak kelurahan sudah keluar, Tim Pelaksana melaksanakan kegiatan IPTEKS bagi masyarakat ini sesuai dengan yang dijadwalkan dengan membawa peralatan dan bahan yang diperlukan. Selama pelaksanaan pelatihan dilakukan juga monitoring dan evaluasi baik dilakukan oleh Tim PPM itu sendiri maupun pihak Lembaga Pengabdian Masyarakat UNESA dengan mendatangi lokasi saat kegiatan berlangsung.

Pelaksanaan Kegiatan IPTEKS bagi masyarakat ini dibagi menjadi dua tahap yaitu: Pertama, pembinaan ketrampilan melalui pelatihan pembuatan kerajinan dengan berbahan enceng gondok. Pelatihan ini diberikan kepada anggota Kelompok Tani Srikandi, terutama ibu-ibu. Tim pelaksana mengusulkan kepada mitra pembinaan pengembangan ekonomi kreatif melalui pemanfaatan enceng gondok dengan teknik anyam dan ditempel melalui kegiatan workshop. Kedua, berupa pembinaan manajemen produksi dan pemasaran melalui pendampingan. Tim memberikan pendampingan dan bimbingan dalam hal manajemen produksi produk kerajinan tersebut hingga sistem pemasarannya. Mitra dibimbing hingga mampu mandiri dalam mengelola produkproduk kerajinan tersebut. Pembinaan manajemen pemasaran yang diberikan berkaitan erat dengan aspek promosi berupa brosur dan $\mathrm{x}$ banner yang digunakan Kelompok Tani ketika mengikuti pameran.

\section{Pembahasan}

Kelompok tani "Srikandi" yang berada di Kelurahan Balasklumprik Kecamatan Wiyung kegiatan-kegiatan yang dilakukan adalah pertemuan rutin sebulan sekali di Balai Kelurahan Balasklumprik yang membahas masalah-masalah rutin pertanian. Biasanya diisi oleh Petugas Penyuluh Lapangan dari Dinas Pertanian Surabaya. Selain itu adapula pertemuan tidak rutin. Pertemuan ini merupakan pertemuan khusus biasanya berupa pelatihan ketrampilan-ketrampilan yang membutuhkan waktu lebih dari sehari pertemuan.

Kegiatan pelatihan yang pernah dilakukan yang berkaitan dengan tanam menanam. antara lain: menanam TOGA (Taman Obat Keluarga, menanam TABULAPOT (Tanaman Buah dalam Pot) maupun menanam sayur-mayur. Sedangkan pelatihan lainnya yang tidak berkaitan dengan tanam-menamam tetapi lebih ditekankan pada pemberdayaan masyarakat. antara lain: membuat cincau Bandung, membuat kue dari singkong, membuat Bakpia Pathok dan mengolah enceng gondok menjadi kerajinan (tas dan kotak). Untuk kerajinan enceng gondok ini sudah mulai berkembang menjadi industri kecil yang dikelola oleh ibu-ibu Kelompok Tani. Hasilnya berupa kotak untuk coklat sudah dipasarkan hingga ke Bali dengan bantuan Disperindag Kota Surabaya. Harga jual kotak coklat tersebut sekitar Rp 10.000 hingga Rp 15.000. Selain kotak coklat yang diproduksi berdasarkan pesanan, kelompok Tani juga memproduksi, alas vas bunga yang juga dibuat berdasarkan pesanan restoran dengan harga berkisar Rp 10.000 per kotak. Sementara ini bahan baku diperoleh dengan membeli pemasok yang sudah kering, jadi kelompok tani hanya tinggal menganyam saja. Hal ini disebabkan belum mendapatkan pelatihan mengenai pengolahan enceng gondok untuk siap anyam padahal di wilayah Balasklumprik terdapat waduk yang ditumbuhi oleh enceng gondok.

Kelompok Tani Srikandi Balasklumprik ini diketuai oleh ibu R.Sri Utari dengan wakilnya Bu Agung serta sekretarisnya Bu Mukti. Didirikan sekitar bulan Mei 2007 dengan PPL Ibu Tri Utami. Kelompok tani ini masih di bawah binaan Dinas Pertanian dengan membantu dalam hal penyediaan bibit dan pupuk bagi anggota. Dinas juga menerjunkan PPL sebagai pemantau dan pembimbing kelompok tani. Pelatihan-pelatihan dan bantuan-bantuan yang berkaitan dengan pertanian dan perikanan juga dikawal oleh 
Dinas Pertanian sedangkan Disperindag membimbing kedua kelompok tani dalam hal pengolahan pertanian menjadi produk dan barang kerajinan yang bisa bernilai ekonomis untuk menambah pendapatan keluarga.

Berdasarkan uraian tersebut, upaya pengembangan di luar hal-hal yang terkait dengan rutinitas kegiatan Kelompok Tani. misalnya dengan memberikan pelatihan ketrampilan membuat suatu karya yang bukan saja menambah ketrampilan anggota tetapi juga berpeluang untuk dikembangkan menjadi sebuah usaha yang mampu memberikan nilai tambah bagi keluarga. Salah satu bidang usaha yang berpeluang untuk dikembangkan adalah usaha kerajinan. Salah satu usaha kerajinan yang dapat dikembangkan dengan modal tidak besar tetapi mampu menghasilkan nilai ekonomi yang cukup tinggi adalah kerajinan anyam dengan menggunakan bahan enceng gondok.

Tanaman enceng gondok banyak tumbuh di sungai wilayah Kelurahan Balasklumprik. Keberadaan enceng gondok sangat menganggu ekosistem di sungai sehingga bila sudah memenuhi sungai akan dibuang di pinggirnya. Melihat potensi alam yang dimiliki kelurahan Balasklumprik dengan melimpahnya enceng gondok yang tidak termanfaatkan maka Tim PPM mengusulkan untuk memberikan pengetahuan alternatif mengolah dan menganyam enceng gondok yang bahan bakunya ada mudah didapat.

Adapun rangkaian kegiatan selama pelaksanaan Pengabdian pada Masyarakat (PpM) adalah sebagai berikut:

\section{Pembuatan Handout dan Prototype}

Penyusunan handout dilakukan di Jurusan Seni Rupa FBS Unesa kampus Lidah Kulon selama tiga hari pada tanggal 5 - 7 Mei 2014, yaitu pengumpulan materi yang akan ditampilkan dalam handout. Materi yang dituangkan berasal dari berbagai sumber pustaka baik dari buku maupun internet. Sumber pustaka tersebut kemudian digabungkan menjadi satu kesatuan handout yang utuh. Di dalam handout ditampilkan langkah-langkah membuat kerajinan dari enceng gondok.

Pembuatan prototype berupa contoh produk yang akan dipresentasikan pada saat pelatihan. Proses pembuatannya dilakukan di Studio Tekstil di Jurusan Seni Rupa Fakultas Bahasa dan Seni Unesa oleh tim pelaksana berjumlah tiga orang dan dibantu dengan 2 orang mahasiswa. Adapun kegunaan prototype ini adalah memberikan gambaran dan contoh hasil akhir dari kegiatan pelatihan. Peserta diharapkan mempunyai gambaran apa yang sedang dikerjakannya dan untuk mengantisipasi keraguankeraguannya tentang karyanya.

Pembuatan prototype dilaksanakan dengan tiga tahapan selama 9 hari. Tahap pertama dilaksanakan selama tiga hari pada tanggal 26- 28 Mei 2015. Diawali dengan pengolahan bahan baku enceng gondok kering menjadi siap anyam. Pengelohannya berupa: pembersihan dari kotoran dengan citrun dan pemutih pakaian, kemudian penghilangan lilin pada permukaan enceng gondok dengan tawas agar warna meresap dengan mudah. Tahap terakhir adalah pewarnaan dengan pewarna makanan dengan direbus. Tahap kedua juga dilaksanakan selama 3 hari pada tanggal 1 - 4 Juni 2015, yaitu: pembuatan baberapa variasi anyam datar, yaitu: anyam sasak terdiri dari: anyam sasak, anyam kepang, anyam udan iris dan anyam pita. Pada tahap ketiga dilaksanakan pada tanggal 8-9 Juni 2015, mempersiapkan beberapa kerangka produk kerajinan untuk dibagikan kepada peserta pelatihan pada saat sosialisai di lokasi. Kerangka yang dibagikan yaitu tempat tisu dan kotak serbaguna. 


\section{Pelaksanaan Pelatihan}

Di awali dengan sosialisasi ke mitra Kelompok Tani RW 02 dan RW 07 Kelurahan Balasklumprik Kecamatan Wiyung Surabaya dilaksanakan di kediaman ketua Kelompok Tani Srikandi Ibu Sri Utari di Jalan Karang Klumprik Utara blok TT 23D, Perumahan Pondok Maritim Indah, pada hari Minggu tanggal 14 Juni 2015 dimulai pukul 09.00 WIB. Kegiatan ini diawali dengan pembukaan oleh Ketua tim pelaksana Ibu Asidigisianti S.P., untuk menyampaikan maksud dan tujuan diadakannya sosialisasi ini. Kemudian tim pelaksana memperkenalkan diri satu persatu. Peserta adalah ibu-ibu Kelompok Tani RW02 dan RW07 Kelurahan Balasklumprik Kecamatan Wiyung Surabaya, yang berjumlah 10 orang.

Pertemuan pertama pelatihan kerajinan dari enceng gondok dilaksanakan pada hari Minggu, tanggal 9 Agustus 2015 tetap di Sri Utari di Jalan Karang Klumprik Utara blok TT 23D, Perumahan Pondok Maritim Surabaya Kelurahan Balasklumprik Kecamatan Wiyung Surabaya. Pukul 09.00 pelatihan dimulai dengan pemberian ulang materi tentang langkah-langkah menganyam datar untuk membuat produk kerajinan berbahan enceng gondok.

Pada pertemuan kali ini dijelaskan cara menganyam datar enceng gondok yang telah diberi warna sebelum ditempelkan pada kerangka kotak dan tempat tisu. Peserta antusias mengikuti pelatihan ini karena menganyam dengan enceng gondok. Sebelum diakhiri pelatihan ini pukul 12.00, karya-karya peserta dievaluaasi dengan memberikan masukan terutama mengenai desain dan kerapian. Masukan atau saran mengenai desain disini berupa bagaimana mengkomposisi warna agar menjadi lebih serasi dan cara-cara alternatif menghias kotak dan tempat tisu.

Pertemuan kedua pelatihan kerajinan dari enceng gondok dengan menggunakan teknik anyam dan ditempel dilaksanakan pada hari Sabtu, 29 Agustus 2015 pukul 09.00 hingga 12.00 di lokasi yang sama. Dimulai dengan memberikan penjelasan singkat mengenai langkah-langkah teknik anyam keranjang. Teknik anyam keranjang merupakan teknik anyam dengan tingkat kesulitan lebih tinggi daripada produk kerajinan kotak dan tempat tisu. Awalnya langkah-langkah menganyam dasarnya berikutnya dan menganyam sisi-sisinya. Produk yang dihasilkan dengan teknik anyam keranjang yaitu: wadah kecil bisa untuk wadah permen dan piring datar. Di akhir pelatihan Tim memberikan apresiasi dan evaluasi terhadap karya-karya peserta satu persatu secara lisan. Evaluasi yang diberikan berupa masukan atas desain dan kerapian dari karya peserta agar peserta bisa memperbaiki lagi karya berikutnya. Pemberian evaluasi lesan ini bertujuan agar peserta mengetahui kekurangan dari karyanya supaya karya tersebut dapat bersaing di pasar dan tidak kalah dengan produk di pasaran yang sudah ada.

Pada hari yang sama di Wilayah RW 07 ada acara Pemerintah Kota Surabaya Road Show 200 Besar RT Terbaik Surabaya Emas Green and Clean 2015 dengan Tema Elok, Mandiri, Asri Sehat yang disponsori oleh Jawa Pos. Dalam acara tersebut terdapat Panggung Hiburan dan pentas yel-yel Finalis Green and Clean Wilayah Surabaya Barat. Di sekitar panggung disediakan tenda-tenda bagi UKM dari RW 07 Kelurahan Balasklumrik untuk pameran menunjukkan kerajinan yang dihasilkan. Kesempatan ini tidak disia-siakan oleh Kelompok Tani Wanita Srikandi juga ikut mengisi tenda UKM tersebut dengan memamerkan karya-karya kerajinan dari enceng gondok yang telah dibuat melalui pelatihan-pelatiahan sebelumnya. Pameran ini selain menjadi ajang promosi kerajinan enceng gondok karya Kelompok Tani Wanita Srikandi juga sebagai ajang uji coba kelayakan produk di masyarakat.

Pelatihan pertemuan ketiga pada hari Sabtu 12 September 2015 jam 09.00-12.00 di tempat yang sama. Dimulai dengan memberikan penjelasan singkat mengenai langkah- 
langkah membuat tas dari enceng gondok dengan teknik anyam. Produk tas merupakan produk dengan tingkat kesulitan paling tinggi daripada produk kerajinan lainnya. Awalnya dijabarkan langkah-langkah menganyam dasar tas kemudian mempraktekkan langkah-langkah menganyam sisi-sisi tas. Selain membuat tas pada pertemuan ketiga ini, produk kerajinan yang telah dihasilkan peserta mulai tempat tisu, kotak tisu di finshing dengan cat semprot clear atau pylox. Hasil finishing ini selain melindungi permukaan produk dari noda juga membuat produk tampak lebih rapi dan mengkilat, juga tahan lama karena hama akan sulit untuk menembus pori-pori enceng gondok tersebut.

Di akhir Tim memberikan evaluasi terhadap karya-karya peserta satu persatu secara lisan. Evaluasi yang diberikan berupa masukan atas desain dan kerapian dari karya peserta agar peserta bisa memperbaiki lagi karya berikutnya. Pemberian evaluasi lisan ini bertujuan agar peserta mengetahui kekurangan dari karyanya supaya karya tersebut dapat bersaing di pasar dan tidak kalah dengan prouk eksisting yang sudah ada.

Selama proses pelatihan Lembaga Penelitian dan Pengabdian Masyarakat UNESA melakukan pemantauan (monev). Tim pelaksana juga mempersiapkan kunjungan tim pemantau baik dari tingkat UNESA maupun tingkat pusat DIKTI. Persiapan monev berupa pengumpulan karya-karya yang telah dibuat peserta dimasukkan ke dalam etalase kaca untuk diperlihatkan kepada tim pemantau.

Setelah tiga kali pertemuan pelatihan diharapkan peserta sudah mampu membuat karya sesuai dengan prototipe yang sudah dicontohkan. Tahapan berikutnya adalah tim pelaksana pengabdian pada masyarakat program IPTEKS bagi Masyarakat adalah melakukan pendampingan yang dilakukan secara intensif bagi ibu-ibu yang benar-benar berminat dengan pengembangan kerajinan dari enceng gondok ini. Pendampingan ini berupa konsultasi karya untuk pengembangan produk kedepannya agar kualitas karya yang dihasilkan para peserta bisa terjaga. Waktu yang disediakan tidak selama program pelatihan Pendampingan dilaksanakan sebanyak dua kali pertemuan yaitu tanggal 19 September dan 3 Oktober tahun 2015. Lokasi pedampingan berpindah-pindah sesuai dengan kebutuhan dari ibu-ibu Kelompok Tani Wanita Srikandi. Selama pendampingan bahan dan alat masih disediakan oleh tim pelaksana.

\section{Perancangan Media Promosi}

Selama proses pelatihan karya-karya ibu kelompok Tani Srikandi yang paling menonjol digunakan sebagai ilustrasi (foto) media promosi. Media promosi ini diperlukan untuk menunjang pemasaran di kemudian hari. Media promosi yang dibuatkan berupa: brosur dan $\mathrm{x}$-banner. Diharapkan media tersebut dapat digunakan ketika mengikuti pameran-pameran di luar ataupun dipasang di kantor Kelurahan Balasklumprik untuk menunjukkan bahwa ibu Kelompok Tani Srikandi Keluruahan Balasklumprik Kecamatan Wiyung mampu memproduksi kerajinan anyam berbahan enceng gondok yang diperoleh dari sekitar tempat tinggalnya.

Brosur dibuat dengan ukuran A5 supaya mudah dibawa dan mudah dibagikan. Brosur menjadi media pendukung banner. Informasi yang dimuat pada brosur ini lebih rinci daripada banner baik alamat maupun produk yang dihasikan. Pada banner produk berupa kotak Tisu dibuat lebih besar dari pada prouuk lain yang karena menjadi pusatperhatian para audiens dan kotak tisu merupakan produk unggulan. Produkproduk lain divisualisasikan lebih kecil Produk-produk tersebut merupakan produk buatan Kelompo Tani Wanita Srikandi. 


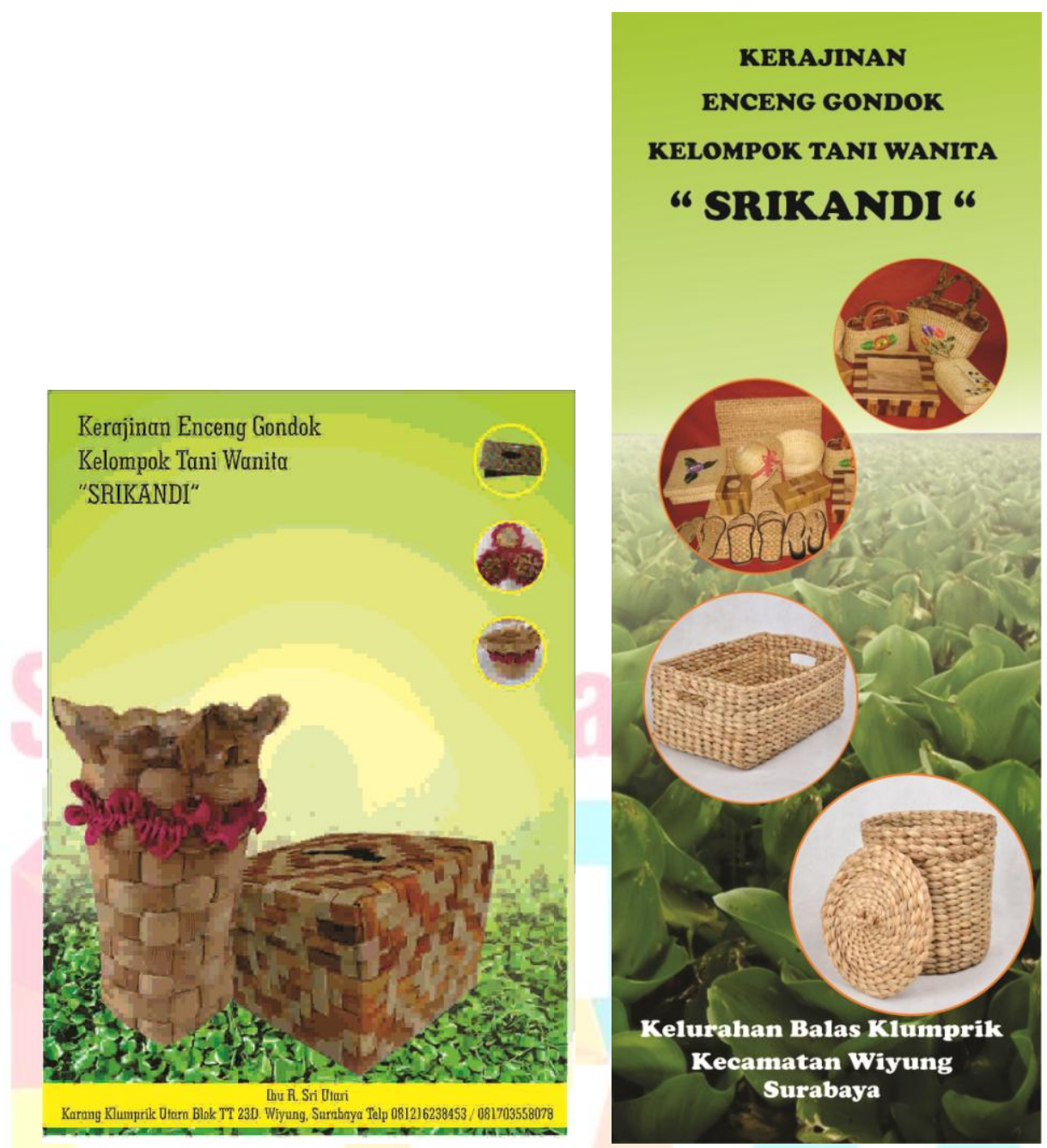

Gambar 1. Desain Brosur dan $x$-banner

Banner digunakan sebagai media Promosi kerajinan Enceng Gondok Kelompok Tani Wanita Srikandi. Standing Banner berukuran 60x160 cm dipasangpada stand saat pameran. Berangkat dari eco green memanfaatkan tanaman enceng gondok yang tumbuh liar banyak di sekitar wilayah Balas Klumprik. Background berupa gambar tanaman enceng gondok dipadukan dengan warna hijau, supaya audien mengetahui tanaman enceng gondok dan warna hijau hanya penyelarasan dari warna enceng gondok tersebut. Judul/Headline 'kerajinanEncengGondokKelompokTaniSrikandi' dibuat dengan jenis huruf Cooper Black berkesan tegas diposisikan center. Hal ini dimaksudkan supaya perhatian audiens tertuju langsung pada judul yang meng informasikan pada pengrajinnya. Subheadline 'Kelurahan Balasklumprik, Kecamatan Wiyung, Surabaya' berwarna putih terletak di bawah memusat dengan ukuran huruf lebih kecil dari headline, supaya audiens setelah membaca judul maka akan membaca sub judul yang menginformasikan tentang tempat/lokasi produksi kerajinan. Ilustrasi berupa gambar produk disusun semakin keatas semakin mengecil sesuai perspektif dimaksudkan untuk mengnformasikan varian produk yang dihasilkan dari kerajinan enceng gondok berkembang dan semakin bervariasi mengikuti mode/tren. 


\section{Deskripsi Karya Peserta}

Selama berlangsungnya kegiatan pelatihan dengan empat kali pertemuan telah menghasilkan berbagai jenis produk kerajinan dari bahan enceng gondok dengan menggunakan beberapa variasi anyaman. Berikut produk kerajinan yang dihasilkan oleh Kelompok Tani Wanita Srikandi Kelurahan Balasklumprik Kecamatan Wiyung Surabaya.

\section{a. Tatakan Gelas}

Tatakan gelas memiliki diamater bervariasi antara $10 \mathrm{~cm}$ berbahan utama enceng gondok. Alat yang digunakan untuk membentuk kerangka dan memotong enceng gondok adalah gunting dan cutter. Teknik yang digunakan adalah anyam. Enceng gondok digunting sedemikian rupa kemudian dianyam. Pinggirannya ditambahkan anyam pita untuk hiasan. Untuk karya kerajinan ini bahan menghabiskan biaya berkisar Rp 500- Rp1.000 dan dapat dijual dengan harga Rp 1.500- Rp 3.000.
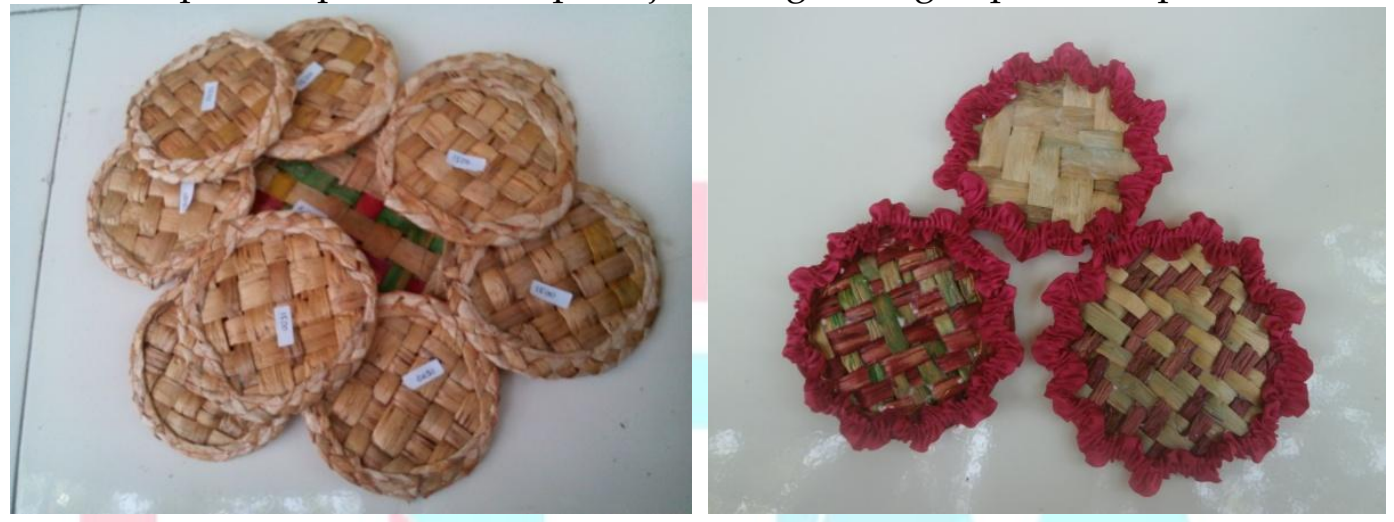

Gambar 2. Tatakan Gelas

b. Kotak Tisu Kecil

Kotak tisu memiliki tinggi $8 \mathrm{~cm}$, lebar $13 \mathrm{~cm}$ dan panjang $13 \mathrm{~cm}$ dan Kotak tisu memiliki tinggi 9,5 cm, lebar $12 \mathrm{~cm}$ dan panjang $25 \mathrm{~cm}$. Berbahan utama enceng gondok. Karton tebal digunakan sebagai kerangka sedangkan untuk merekatkan menggunakan lem. Alat yang digunakan untuk membentuk kerangka dan memotong enceng gondok adalah gunting dan cutter. Teknik yang digunakan adalah teknik anyam dan ditempel. Enceng gondok digunting sedemikian rupa kemudian dianyam lalu ditempel di kerangka. Untuk karya kerajinan ini bahan menghabiskan biaya berkisar Rp 5.000 dan dapat dijual dengan harga Rp 15.000 -Rp 25.000.
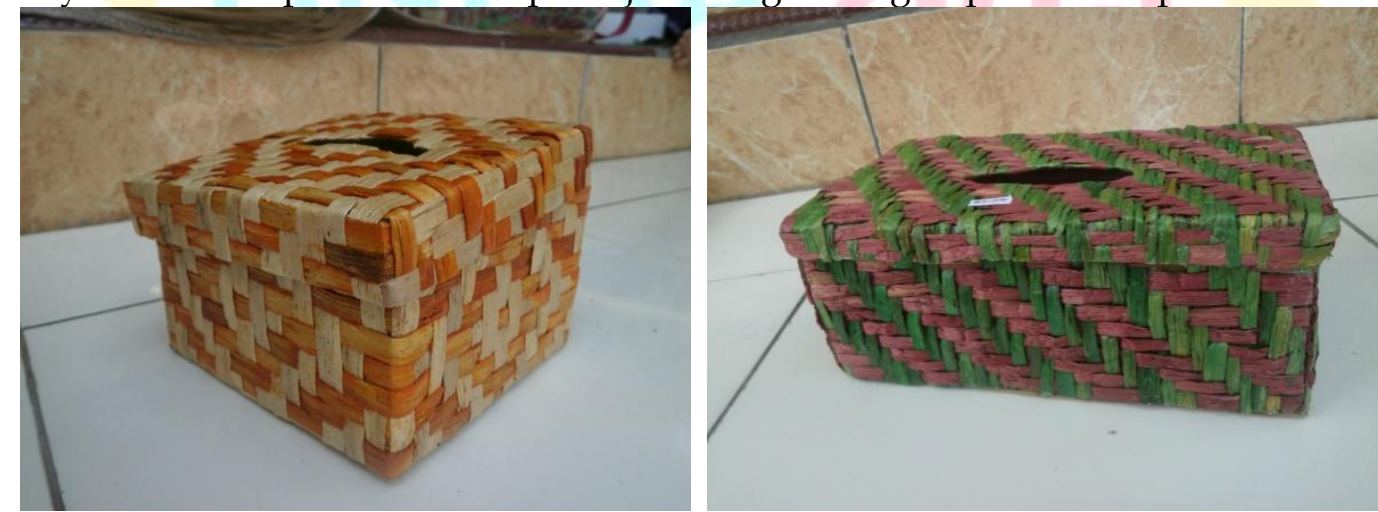

Gambar 3. Kotak Tisu

c. Tempat Permen

Tempat permen memiliki tinggi bervariasi antara $7 \mathrm{~cm}$ hingga $9 \mathrm{~cm}$ dengan diameter $6 \mathrm{~cm}$ berbahan utama enceng gondok. Alat yang digunakan untuk memotong enceng gondok adalah gunting dan cutter. Tidak menggunakan kerangka. Teknik yang digunakan adalah teknik anyam keranjang. Enceng gondok digunting 
sedemikian rupa kemudian dianyam. Awalnya menganyam dasar kemudian naik ke sisinya. Sebagai hiasan ditempelkan pita. Sebagai acuan (mal) menggunakan gelas kaca agar ukurannya sama. Untuk karya kerajinan ini bahan menghabiskan biaya berkisar Rp 1.000 dan dapat dijual dengan harga Rp 3.000.

d. Piring

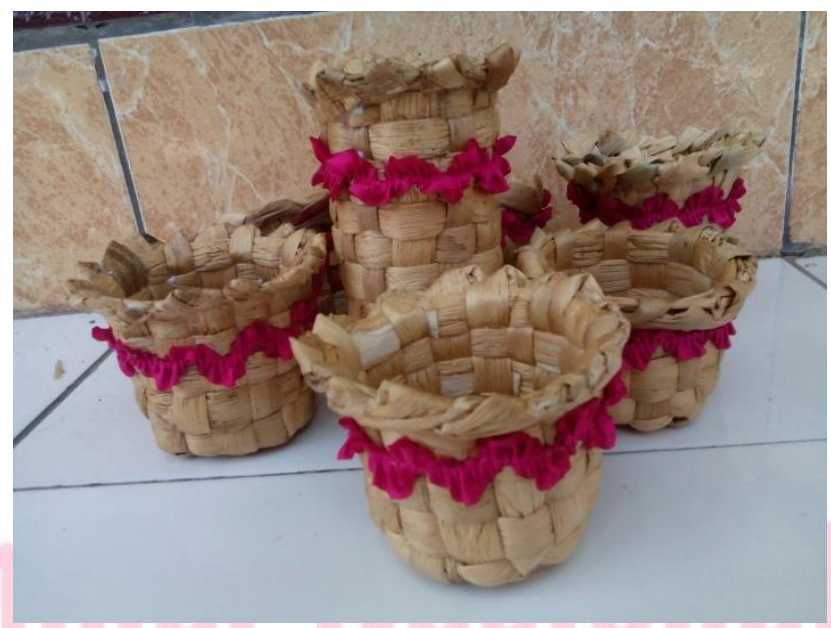

\section{Gambar 4. Tempat Permen dari Enceng Gondok}

Piring memiliki diamater bervariasi antara $17 \mathrm{~cm}, 22 \mathrm{~cm}$ hingga $26 \mathrm{~cm}$ berbahan utama enceng gondok. Alat yang digunakan untuk memotong enceng gondok adalah gunting dan cutter. Tidak menggunakan kerangka. Teknik yang digunakan adalah teknik anyam keranjang. Enceng gondok digunting sedemikian rupa kemudian dianyam. Sebagai acuan (mal) mengunakan piring agar ukurannya sama. Untuk karya kerajinan ini bahan menghabiskan biaya berkisar Rp 2.000 dan dapat dijual dengan harga Rp 5.000.

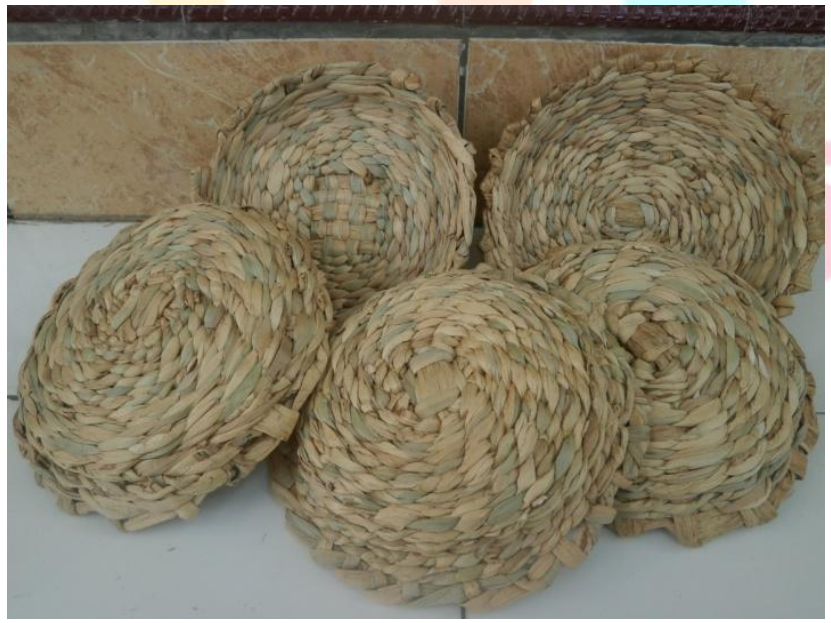

Gambar 5. Pirirng dari Enceng Gondok

\section{Simpulan}

Kesimpulan yang dapat disampaikan oleh Tim Pelaksana PpM adalah: pelaksanaan kegiatan pengabdian kepada masyarakat program IPTEKS bagi Masyarakat dimulai penyusunan modul, pembuatan prototype, hingga sosialisasi dilaksanakan dengan lancar. Kegiatan sosialisasi satu kali pertemuan dan pelatihan selama tiga kali. Kegiatan sosialisasi dilasanakan pada hari minggu tanggal 14 Juni 2015 dimulai pukul 09.00WIB 
dan berakhir pukul 11.00. WIB di kediaman ibu Sri Utari selaku ketua Kelompok Tani Wanita Srikandi di jalan Karang Klumprik Utara Blok TT 23D Perum. Pondok Maritim Indah, Kelurahan Balasklumprik Kecamatan Wiyung Surabaya. Sedangkan pertemuan pertama pelatihan pada hari Minggu tanggal 9 Agustus 2015, pertemuan kedua Sabtu pada tanggal 29 Agustus 2015 dan pertemuan terakhir yaitu pada hari Sabtu tanggal 12 September 2015. Produk kerajinan yang dihasilkan adalah tatakan gelas, kotak tisu kecil dan besar, piring, tempat permen, dan keranjang kotak. Selain menghasilkan keluaran berupa produk-produk kerajinan dari enceng gondok, Tim PpM juga membuat media Promosi yang digunakan untuk membantu memasarkan produk-produk kerajinan tersebut nantinya. Media promosi yang dihasilkan berupa $\mathrm{x}$-banner dan brosur. Kedua media promosi ini diharapkan bisa di-display ketika ibu-ibu Kelompok Tani Wanita Srikandi untuk mengikuti pameran produk unggulan daerah.

\section{Daftar Acuan}

Mutmainah, Siti. 2014. Karya Kerajinan Anyam dalam Upacara Tradisional di Indonesia. Jurnal Seni dan Budaya Padma Vol 9. No 2. September 2014, hal 29-38.

Mutmainah, Siti. 2014. Buku Ajar: Kriya Anyam. Surabaya: Jurusan Seni Rupa Fakultas Bahasa dan Seni UNESA.

Syamsudin. n.d. Kerajinan Anyam, Widyaiswara PPPPTK Seni dan Budaya Yogyakarta, diakses pada tanggal 21 Mei 2015 dari www.pppgkes.com/index.php?...kerajinananyam.

Tocharman, Maman. 2009. Melestarikan Budaya Kriya Anyam. Makalah ini disampaikan pada kegiatan Workshop Anyaman dan Gerabah Di Museum Sri Baduga Bandung - Jawa Barat. Tanggal, 22 Desember 2009.

Widjaja, Elizabeth A., Mahyar, Uway W., \& Utama, Sutikno S. 1989. Tumbuhan Anyaman Indonesia. Jakarta: Mediyatama Sarana Perkasa.

http://perundangan.pertanian.go.id/admin/file/Permentan\%20No.82\%20Tahun $\% 20201$ 3.pdf Diunduh tanggal 13 Oktober 2015.

www.kompasiana.com 13 Oktober 2015. 


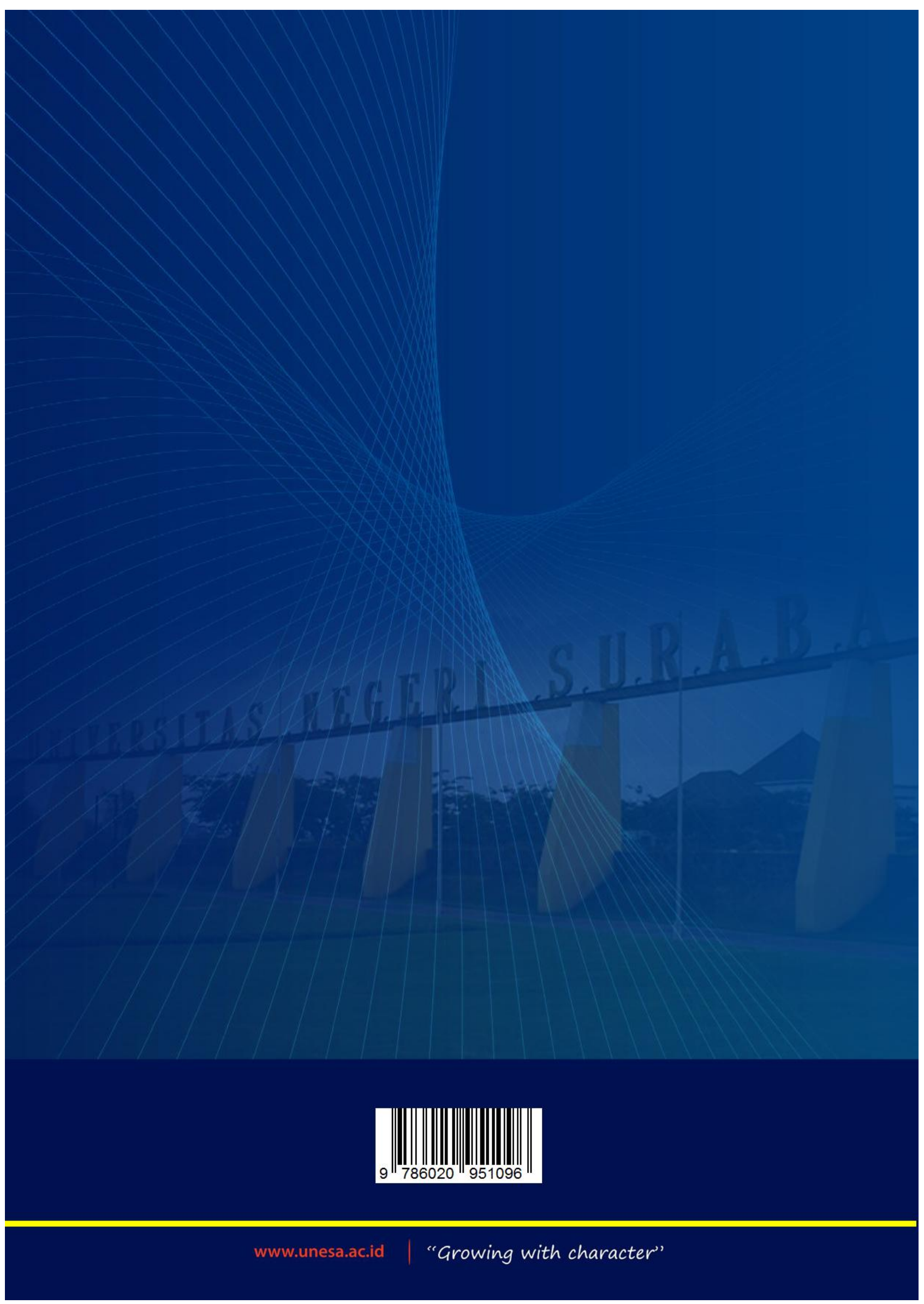

